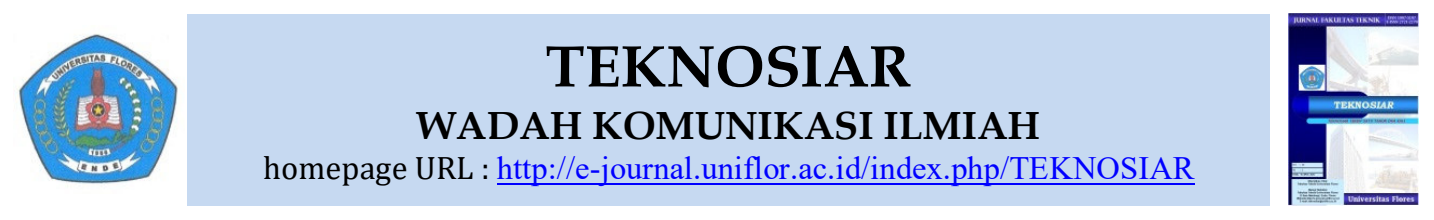

\title{
Analisis Pengaruh Penggunaan Abu Bata Hebel Pada Campuran Beton Terhadap Kuat Lentur Balok Beton
}

\author{
Meiske Cunradiana ${ }^{1}$, *Fransikus X. Ndale ${ }^{2}$, Yohanes Laka Suku ${ }^{3}$ \\ ${ }^{1}$ Alumni Program Studi Teknik Sipil, Fakultas Teknik, Universitas Flores, Ende \\ ${ }^{2,3}$ Program Studi Teknik Sipil, Fakultas Teknik, Universitas Flores, Ende \\ *) Correspondence, e-mail: milanonet66@gmail.com
}

Received: 09-09-2020 Revised: 14-09-2020 Accepted: 20-10-2020

\begin{abstract}
ABSTRAC
The use of additives in the form of chemicals and minerals is expected to increase the strength and characteristics of the concrete mixture, according to the conditions and objectives planned. This study utilizes hebel brick waste as a concrete mixture that has been processed into ashes from the results of sieve test number 200. The purpose of this study was to determine the effect of variation and ash content of hebel bricks on the flexural strength of concrete. The method in this study uses the Indonesian National Standard (SNI). The results obtained indicate that the maximum flexural strength of concrete blocks is $4 \mathrm{MPa}$ with $10 \%$ hebel ash content at 28 days of age, has met and exceeds the flexural strength of normal concrete beams. The strength behavior of concrete increases linearly. The optimum hebel brick ash content is $10 \%$ which can increase the flexural strength of concrete blocks above the flexural strength of normal concrete blocks. This is inversely proportional to the percentage of addition of $30 \%$ and $50 \%$, the results obtained have decreased strength.
\end{abstract}

Keywords: concrete, flexural strength, hebel brick

\begin{abstract}
ABSTRAK
Penggunaan bahan aditif berupa bahan kimia dan mineral diharapkan dapat meningkatkan kekuatan dan karakteristik campuran beton, sesuai dengan kondisi dan tujuan yang direncanakan. Penelitian ini memanfaatkan limbah bata hebel sebagai campuran beton yang telah diolah menjadi abu dari hasil uji lolos ayakan nomor 200. Tujuan penelitian ini adalah untuk mengetahui pengaruh variasi dan kadar abu bata hebel terhadap kuat lentur beton. Metode dalam penelitian ini menggunakan Standar Nasional Indonesia (SNI). Hasil yang diperoleh menunjukkan bahwa kuat lentur maksimum balok beton adalah 4 MPa dengan kadar abu hebel 10\% pada umur 28 hari, telah memenuhi dan melebihi kuat lentur balok beton normal. Perilaku kekuatan beton meningkat secara linier. Kadar abu bata hebel optimum sebesar 10\% yang dapat meningkatkan kuat lentur balok beton diatas kuat lentur balok beton normal. Hal ini berbanding terbalik dengan persentase penambahan $30 \%$ dan $50 \%$, hasil yang didapat mengalami penurunan kekuatan.
\end{abstract}

Kata kunci: beton,kuat lentur,bata hebel

TEKNOSIAR Volume 14, No.02, Oktober 2020

p-ISSN 1907-5197 (versi cetak) e-ISSN 2721-2270 (versi online) 


\section{PENDAHULUAN}

Beton adalah suatu campuran yang terdiri dari pasir, kerikil, batu pecah, atau agregat-agregat lain yang dicampur menjadi satu dengan suatu pasta yang terbuat dari semen dan air membentuk suatu massa mirip batuan. Terkadang, satu atau lebih bahan aditif ditambahkan untuk menghasilkan beton dengan karakteristik tertentu, seperti kemudahan pengerjaan (workability), durabilitas, dan waktu pengerasan. Beton digunakan untuk membuat berbagai macam konstruksi seperti struktur bangunan,perkerasan jalan,pondasi dan jembatan.

Penggunaan bahan tambah material dengan ukuran partikel sangat halus sebagai bahan penyusun beton seperti abu terbang, silica fume, dan tepung marmer terbukti berhasil dalam meningkatkan sifat mekanik beton normal, beton mutu tinggi dan reactive powder concrete (Kushartomo et al., 2013). Guna meningkatkan kekuatan dan karakteristik campuran beton sesuai dengan kondisi dan tujuan yang direncanakan,penelitian ini memanfaatkan limbah bata hebel sebagai bahan campuran beton yang telah diproses menjadi abu dari hasil lolos saringan no 200. Proses pengolahan bahan tambah tersebut sesuai dengan standar pemberian bahan tambahan beton tentang Spesifikasi Bahan Tambahan pada Beton. (SNI S-18-1990-03)

Tujuan penelitian ini untuk mengetahui pengaruh variasi dan kadar abu bata hebel pada campuran beton terhadap kuat lentur balok beton.

\section{Tinjauan Pustaka}

Beberapa penelitian beton dengan campuran bahan tambah antara lain; Studi Penggunaan Silica Fume Sebagai Bahan Pengisi (Filler) Pada Campuran Beton. Hasil penelitian menunjukkan kuat tekan beton normal pada umur 28 hari yaitu $37,10 \mathrm{Mpa}$, untuk penambahan $5 \%$ silica fume f'c $=$ 40,39 Mpa, dan untuk penambahan 10\% silica fume f' $\mathrm{c}=41,88 \mathrm{Mpa}$. Kemudian untuk penambahan $15 \%$ silica fume f'c $=43,62 \mathrm{Mpa}$,(Taru, Johan, dan Bandaso). Penambahan pecahan bata ringan untuk mengganti sebagian agregat halus dengan variasi $0 \%, 5 \%, 10 \%, 15 \%$ dan $20 \%$. Hasil kuat tekan beton maksimal dari variasi pecahan bata ringan sebesar $0 \%$ sampai $20 \%$ pada umur 28 hari sebesar 16,176 $\mathrm{MPa}$, melebihi kuat tekan yang telah direncanakan yaitu $\mathrm{f}^{\prime} \mathrm{c}=14,5 \mathrm{Mpa}$ (Yulian,Yudha,Adhityatama.2016).

\section{Bahan Penyusun Beton}

Bahan pembentuk beton adalah gabungan atau sekumpulan interaksi mekanis dan kimiawi dari bahan pembentuknya yang terdiri dari agregat halus dan kasar. Semen dan air berinteraksi secara kimiawi untuk mengikat partikel-partikel agregat tersebut menjadi suatu massa yang padat. Keawetan, kekuatan dan sifat-sifat lain dari beton tergantung dari bahan-bahan penyusunya. Untuk menjamin agar beton yang dihasilkan memenuhi persyaratan yang diminta, terlebih dahulu agregat yang akan digunakan harus diuji terlebih dahulu sebelum mix design beton. Jenis pengujian bahan penyusun beton dapat dilihat pada Tabel 1 dan Tabel 2:

Tabel 1. Jenis Pengujian Agregat Kasar

\begin{tabular}{ll}
\hline \multicolumn{2}{c}{ Agregat Kasar } \\
\hline Pengujian & Standar \\
\hline Gradasi Butiran & SNI 03-1968-1990 \\
\hline Kelembaban & SNI 03-1968-1990 \\
\hline Berat Volume & ASTM C 29-78 \\
\hline Kadar Keausan & SNI 03-2417-1991 \\
\hline Berat Jenis (SSD) & SNI 03-1968-1990 \\
\hline Penyerapan Air & SNI 03-1968-1990 \\
\hline
\end{tabular}

TEKNOSIAR Volume 14, No.02, Oktober 2020 p-ISSN 1907-5197 (versi cetak) e-ISSN 2721-2270 (versi online) 
Meiske Cunradiana,F.X.Ndale, Yohanes Laka Suku

Analisis Pengaruh Penggunaan Abu Bata Hebel Pada Campuran Beton Terhadap Kuat Lentur Balok Beton

\begin{tabular}{ll}
\hline Kadar Lumpur & SNI 03-4142-1996 \\
\hline Fine Modulus (FM) & SNI 03-1968-1990 \\
\hline
\end{tabular}

Tabel 2. Jenis Pengujian Agregat Halus

\begin{tabular}{ll}
\hline & Agregat Halus \\
\hline Pengujian & Standar \\
\hline Gradasi Butiran & ASTM C 136-78 \\
\hline Kelembaban & ASTM C 556-71 \\
\hline Berat Volume & ASTM C 136-78 \\
\hline Berat Jenis (SSD) & ASTM C 136-78 \\
\hline Volume Pengembangan & ASTM C 556-71 \\
\hline Kadar Lumpur & SNI 03-4142-1996 \\
\hline Fine Modulus (FM) & ASTM C 136-78 \\
\hline
\end{tabular}

\begin{abstract}
Abu Bata Hebel
Bata Hebel adalah batu bata yang memiliki berat jenis lebih ringan dari pada bata pada umumnya. Ada 2 macam jenis bata ringan (Aerated Lightweight Concrete /ALC) atau sering disebut juga (Autoclaved Aerated Concrete / AAC) dan CLC (Cellular Lightweight Concrete). Bata ringan AAC adalah beton selular dimana gelembung udara yang ada disebabkan oleh reaksi kimia, yaitu ketika bubuk aluminium atau aluminium pasta mengembang seperti pada prosess pembuatan roti saat penambahan ragi untuk mengembangkan adonan. Material pembuatan bata ringan AAC memakai pasir khusus yaitu silika (>95\% $\mathrm{SiO} 2)$ dan harus digiling sampai ukuran mikro. Sama halnya seperti pada pembuatan roti pada AAC tingkat ekspansi adonan juga tidak bisa di kontrol secara tepat sehingga biasanya akan mengembang keluar dari cetakan. Oleh karena itu harus dipotong untuk mendapatkan dimensi yang dibutuhkan. Gelembung udara yang relatif banyak memungkinkan dihasilkannya AAC dengan kerapatan yang rendah yaitu sekitar $700-800 \mathrm{~kg} / \mathrm{m}^{3}$. Kepadatan yang didapatkan dapat disesuaikan mulai dari $350 \mathrm{~kg} / \mathrm{m}^{3}$ sampai $1.800 \mathrm{~kg} / \mathrm{m}^{3}$ dan kekuatan dapat juga dicapai dari serendah 1,5 sampai lebih $30 \mathrm{~N} / \mathrm{mm}^{2}$. Beton dengan kepadatan di atas $1.200 \mathrm{~kg} / \mathrm{m}^{3}$. Kegunaan dari abu bata ringan adalah untuk mencegah keretakan pada beton apabila sudah mengering. Karena dengan adanya abu bata ringan akan mengurangi penyusutan yang terjadi mulai dari percetakan hingga pengeringan.
\end{abstract}

\title{
Mix Design Beton
}

Mix Design adalah proses merancang dan memilih bahan yang cocok dan menentukan proporsi relatif dengan tujuan memproduksi beton dengan kekuatan tertentu, daya tahan tertentu dan seekonomis mungkin. Proporsi bahan beton di laboratorium memerlukan penyesuaian modifikasi dan kembali disesuaikan dengan kondisi lapangan. Perancang struktur menentukan kekuatan minimum tertentu dari desain campuran beton dengan pengetahuan bahan, kondisi lokasi dan standar pengawasan yang tersedia pada tempat kerja untuk mencapai kekuatan minimum dan daya tahan yang baik.

\section{Kuat Lentur Beton}

Metode pengujian kuat lentur beton dengan balok sederhana yang dibebani terpusat langsung mempunyai tujuan untuk memperoleh kuat lentur beton untuk keperluan perencanaan struktur. Pada setiap penampang terdapat gaya-gaya dalam yang dapat diuraikan menjadi komponenkomponen yang saling tegak lurus dan menyinggung terhadap penampang tersebut. Komponen-

TEKNOSIAR Volume 14, No.02, Oktober 2020 
komponen yang tegak lurus terhadap penampang tersebut merupakan tegangan-tegangan lentur (tarik pada salah satu sisi di daerah sumbu netral dan tekan pada sisi penampang lainnya). Fungsi dari komponen ini adalah untuk memikul momen lentur pada penampang.

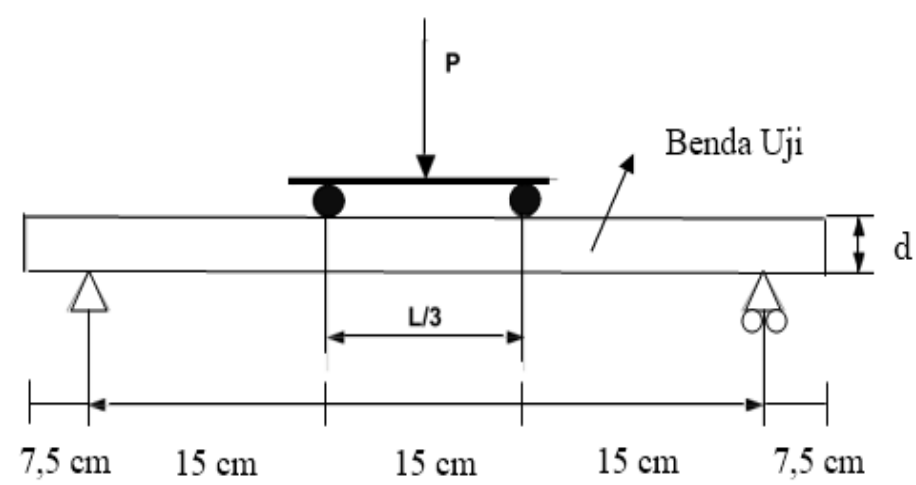

Gambar 1. Pengujian Kuat Lentur Beton

Kuat lentur (modulus of rupture) dapat dihitung dengan persamaan 1, jika bidang patah terletak di daerah pusat ( daerah 1/3 jarak titik perletakan bagian tengah). (SNI 4431:2011)

$$
f l t=\frac{P L}{b h^{2}} .
$$

Persamaan 2, digunakan jika patahan benda uji ada diluar pusat (1/3 jarak titik perletakan bagian tengah), dan jarak titik pusat dan titik patah kurang dari $5 \%$ dari jarak antara titik perletakan. (SNI 4431:2011)

$$
f l t=\frac{3 P a}{b h^{2}}
$$

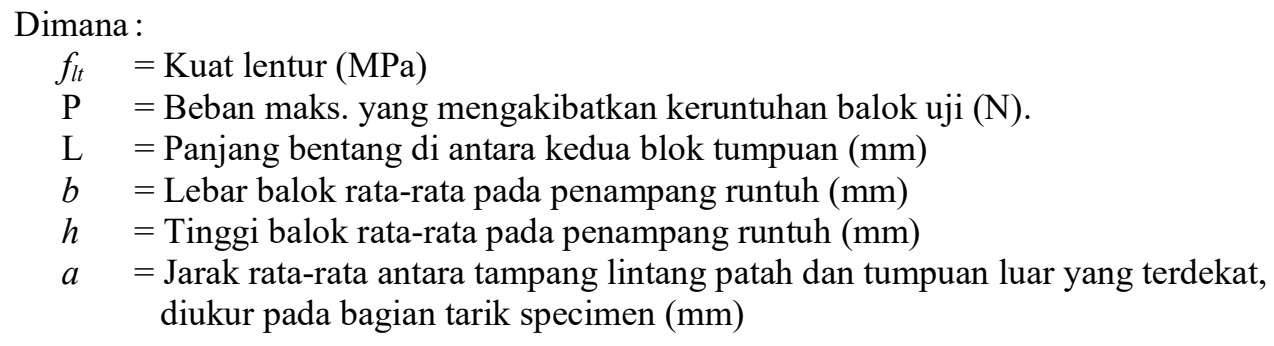

\section{METODE}

\section{Alat dan Bahan}

Alat-alat yang digunakan tersedia di Laboratorium Program Studi Teknik Sipil Fakultas Teknik, Universitas Flores. Sedangkan bahan yang digunakan terdiri dari agregat kasar, agregat halus dan bata hebel berasal dari wilayah Kabupaten Ende.

TEKNOSIAR Volume 14, No.02, Oktober 2020 


\section{Tahapan Penelitian}

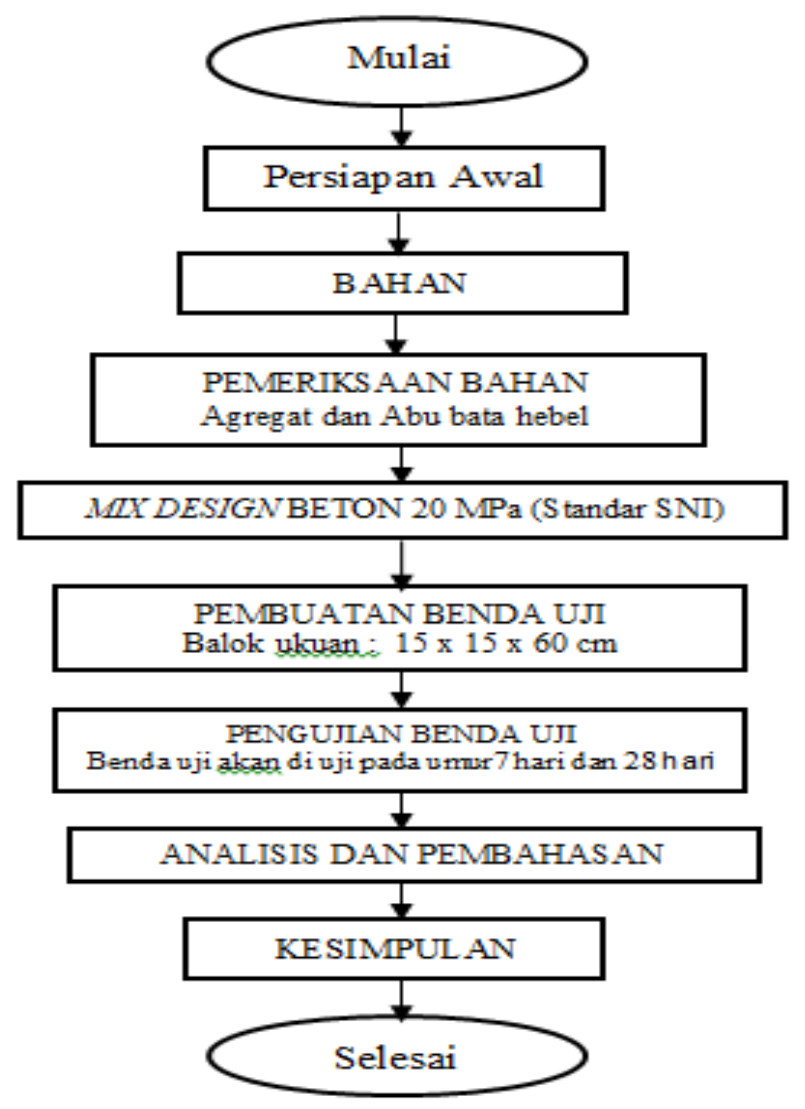

Gambar 1. Tahapan Penelitian

\section{HASIL DAN PEMBAHASAN}

\section{Karakteristik Bahan}

Hasil analisis pengujian karakteristik bahan dapat dilihat pada Tabel 3 dan Tabel 4:

Tabel 3. Hasil Analisa Agregat Kasar

\begin{tabular}{llll}
\hline No. & \multicolumn{1}{c}{ Percobaan } & \multicolumn{1}{c}{ Hasil } & Nilai Standar \\
\hline 1 & Gradasi Butiran & $12,70-25.40 \mathrm{~mm}$ & \\
\hline 2 & Kelembaban & $2.4 \%$ & - \\
\hline 3 & Berat Volume & $1.33 \mathrm{gram} / \mathrm{cm}^{3}$ & $\leq 27 \%$ \\
\hline 4 & Kadar Keausan & $22.88 \%$ & $2,5-2,7 \mathrm{Kg} / \mathrm{dm}^{3}$ \\
\hline 5 & Berat Jenis (SSD) & 2.52 & - \\
\hline 6 & Penyerapan Air & $3.6 \%$ & $\leq 5 \%$ \\
\hline 7 & Kadar Lumpur & $0.2 \%$ & \\
\hline 8 & Fine Modulus (FM) & 4,38 & \\
\hline \multicolumn{5}{l}{ Sumber $:$ Hasil Analisis } &
\end{tabular}

Hasil Analisa agregat kasar dari Tabel 3 menunjukkan bahwa gradasi butiran berkisar 12,70 $25,40 \mathrm{~mm}$,tingkat kelembaban berkisar $2,4 \%$,kadar keausan $22,88 \%$ memenuhi standar $\leq 27 \%$,

TEKNOSIAR Volume 14, No.02, Oktober 2020 
Berat jenis dalam kondisi SSD sebesar 2,52 juga memenuhi standar di kisaran 2,5 sampai dengan $2,7 \mathrm{Kg} / \mathrm{dm}^{3}$. Nilai penyerapan air dan nilai berat volume, kadar lumpur dibawah $\leq 5 \%$ memenuhi standar dan nilai Fine Modulus sebesar 4,38

Tabel 4. Hasil Analisa Agregat Halus

\begin{tabular}{clll}
\hline No. & \multicolumn{1}{c}{ Percobaan } & \multicolumn{1}{c}{ Hasil } & Nilai Standar \\
\hline 1 & Gradasi Butiran & Zona 1 & \\
\hline 2 & Kelembaban & $2.26 \%$ & $5 \%$ \\
\hline 3 & Berat Volume & $1.48 \mathrm{gram} / \mathrm{cm} 3$ & $\leq 95$ \\
\hline 4 & Volume Pengembangan & $9.54 \%$ & - \\
\hline 5 & Berat Jenis (SSD) & 2.13 & $2,5-2,7 \mathrm{Kg} / \mathrm{dm}^{3}$ \\
\hline 6 & Kadar Lumpur & $3.09 \%$ & $\leq 5 \%$ \\
\hline 7 & Fine Modulus & 3.29 & \\
\hline
\end{tabular}

Sumber : Hasil Analisis

Hasil analisa agregat halus dari Tabel 4 menunjukkan bahwa gradasi butiran masuk dalam Zona1, tingkat kelembaban agregat 2,26\% masih dibawah 5\% nilai ini memenuhi standar,berat volume,dan volume pengembangan telah memenuhi spesifikasi, sedangkan berat jenis agregat dalam kondisi SSD sebesar 2,13 nilai ini masuk di antara $2,5-2,7 \mathrm{Kg} / \mathrm{dm}^{3}$ dari standar yang ditentukan, nilai kadar lumpur dibawah $\leq 5 \%$ memenuhi standar dan nilai Fine Modulus sebesar 3,29.

\section{Kuat Lentur Balok Beton}

Tabel 5. Hasil analisis pengujian kuat lentur balok beton umur 7 hari

\begin{tabular}{ccccc}
\hline $\begin{array}{c}\text { Umur } \\
\text { (hari) }\end{array}$ & $\begin{array}{c}\text { Variasi } \\
\text { abu (\%) }\end{array}$ & $\begin{array}{c}\text { Rekapitulasi hasil } \\
\text { Kuat Lentur } \\
(\mathrm{Mpa})\end{array}$ & $\begin{array}{c}\text { Perubahan Kuat } \\
\text { Lentur (Mpa) }\end{array}$ & $\begin{array}{c}\text { Persentase } \\
\text { Perubahan Kuat } \\
\text { Lentur (\%) }\end{array}$ \\
\hline 7 & 0 & 2,62 & 0 & 0 \\
\cline { 2 - 5 } & 10 & 2,76 & 0,14 & 5,34 \\
\cline { 2 - 5 } & 30 & 2,04 & $-0,58$ & $-22,14$ \\
\hline 50 & 1,84 & $-0,78$ & $-29,77$ \\
\hline
\end{tabular}

Sumber : Hasil Analisis

Hasil analisa pada Tabel 5, kuat lentur balok beton normal adalah sebesar 2,62 MPa, sedangkan kuat lentur balok beton dengan tambahan abu bata hebel $10 \%$ menunjukkan kenaikan 5,34\% yaitu sebesar 2,76 MPa pada umur 7 hari dengan perubahan kenaikan sebesar $0,14 \mathrm{MPa}$, sedangkan penambahan abu bata hebel $30 \%$ dan 50\% kuat lentur balok beton mengalami penurunan kekuatan.

Tabel 6. Hasil analisis pengujian kuat lentur balok beton umur 28 hari

\begin{tabular}{ccccc}
\hline $\begin{array}{c}\text { Umur } \\
\text { (hari) }\end{array}$ & $\begin{array}{c}\text { Variasi } \\
\text { abu (\%) }\end{array}$ & $\begin{array}{c}\text { Rekapitulasi hasil } \\
\text { Kuat Lentur } \\
\text { (Mpa) }\end{array}$ & $\begin{array}{c}\text { Perubahan Kuat } \\
\text { Lentur (Mpa) }\end{array}$ & $\begin{array}{c}\text { Persentase } \\
\text { Perubahan Kuat } \\
\text { Lentur (\%) }\end{array}$ \\
\hline 28 & 0 & 3,68 & 0 & 0,00 \\
\cline { 2 - 5 } & 10 & 4 & 0,32 & 8,70 \\
\cline { 2 - 5 } & 30 & 2,24 & $-1,44$ & $-39,13$ \\
\hline 50 & 1,8 & $-1,88$ & $-51,09$
\end{tabular}

Sumber : Hasil Analisis

TEKNOSIAR Volume 14, No.02, Oktober 2020 
Hasil analisa pada Tabel 6, kuat lentur balok beton normal adalah sebesar 3,68 MPa, kuat lentur balok beton dengan tambahan abu bata hebel $10 \%$, menunjukkan kenaikan $8,7 \%$ yaitu sebesar 4 MPa dengan perubahan kenaikan kekuatan sebesar $0,32 \mathrm{MPa}$ pada umur 28 hari, sedangkan penambahan abu bata hebel $30 \%$ dan $50 \%$ kuat lentur balok beton mengalami penurunan. Laju kenaikan kuat lentur balok beton dari umur 7 hari sampai dengan 28 hari dapat dilihat pada Gambar2 dibawah ini.

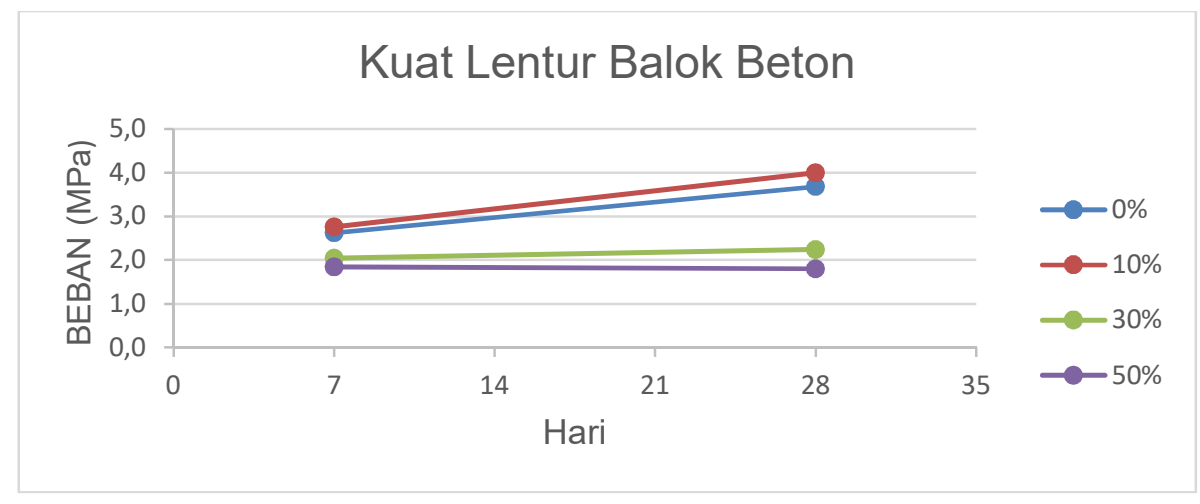

Gambar 2. Grafik laju kenaikan kuat lentur balok beton

Berdasarkan Gambar 2, kuat lentur balok beton dengan tambahan abu bata hebel $10 \%$ menunjukkan laju kenaikan kekuatan bertambah secara linear dari umur 7 hari sampai dengan 28 hari, kandungan abu hebel 30\% laju kenaikan kekuatan cenderung melandai dari umur 7 hari sampai dengan 28 hari, sedangkan kandungan abu hebel 50\% mengalami penurunan kekuatan dari umur 7 hari sampai dengan 28 hari mengalami penurunan.

\section{KESIMPULAN}

Berdasarkan hasil analisis dan pembahasan, maka dapat disimpulkan sebagai berikut :

1. Kuat lentur balok beton maksimum sebesar $4 \mathrm{MPa}$ dengan kandungan abu hebel $10 \%$ pada umur 28 hari, telah memenuhi dan melampaui kuat lentur balok beton normal dengan perilaku kenaikan kekuatan secara linier.

2. Kadar optimum abu bata hebel $10 \%$ dapat meningkatkan kuat lentur balok beton di atas kuat lentur balok beton normal. Hal ini berbanding terbalik dengan persentase penambahan abu bata hebel 30\% dan 50\% hasil yang diperoleh mengalami penurunan kekuatan.

\section{UCAPAN TERIMA KASIH}

1. Terima kasih kepada Kepala Laboratorium Teknik Sipil Universitas Flores

2. Terima kasih kepada pihak-pihak yang telah membantu dalam proses penelitian

\section{DAFTAR PUSTAKA}

ASTM Internasional. (2002). Standar Test Method for Compressive Strength of Concrete, Section 4, Vol.04.02, ASTM C39.

TEKNOSIAR Volume 14, No.02, Oktober 2020 p-ISSN 1907-5197 (versi cetak) e-ISSN 2721-2270 (versi online) 
ASTM Internasional. (2002). Standar Test Method for Flexural Strength of Clyndrical Speciments, Section 4, Vol.04.02, ASTM C78.

ASTM Internasional. (2002). Standar Test Method for Splitting Tensile Strength of Clyndrical Concrete Speciments, Section 4, Vol.04.02, ASTM C496.

Basuki. 2018. Bata Ringan. Diambil pada tanggal 14 Oktober 2018 dari https://id.wikipedia.org/wiki/Bataringan.

Badan Standarisasi Nasional. (2011). SNI 03-4431-2011. Cara Uji Kuat Lentur Beton Nasional dengan Dua Titik Pembebanan. Bandung: Badan Standarisasi Nasional.

Badan Standarisasi Nasional. (1990). SNI S-18-1990-03. Spesifikasi Bahan Tambahan Pada Beton. Jakarta: Badan Standarisasi Nasional.

Mulyono, T. 2005. Teknologi Beton. Yogyakarta: Andi.

Purwati. 2014. Pengaruh Ukuran Butiran Terhadap Kuat Tekan Dan Modulus Elastisitas Beton Kinerja Tinggi Grade 80. Jurnal Arsitektur Universitas Bandar Lampung.

Yulian Yudha Adhityatama. 2016. Analisis pengaruh penambahan pecahan bata ringan sebagai pengganti sebagian agregat halus terhadap kuat tekan beton.

Susilowati. 2011. Pemanfaatan Serbuk Marmer Sebagai Bahan Alternatif Pengganti Semen Pada Campuran Beton Normal. Jurnal Arsitektur Universitas Bandar Lampung.

Rani Oktaviani Tarru. Studi Penggunaan Silica Fume Sebagai Bahan Pengisi (Filler) Pada Campuran Beton.: Program Studi Teknik Sipil, Fakultas Teknik, Universitas Kristen Indonesia Toraja.

TEKNOSIAR Volume 14, No.02, Oktober 2020 